\title{
RAD51D wt Allele
}

National Cancer Institute

\section{Source}

National Cancer Institute. RAD51D wt Allele. NCI Thesaurus. Code C116931.

Human RAD51D wild-type allele is located in the vicinity of $17 q 11$ and is approximately 22 $\mathrm{kb}$ in length. This allele, which encodes DNA repair protein RAD51 homolog 4 protein, is involved in DNA repair. Mutation of the gene is associated with susceptibility to familial breast-ovarian cancer type 4 . 